\title{
Temporally Adrift and Permanently Liminal: Relations, Distalgia and a U.S. University as Site of Transition and Frontier
}

\author{
By Frank G. Karioris
}

\begin{abstract}
This article seeks to explore temporal reconceptualizations and forms of nostalgia that first-year university men are experiencing and creating. It will explore the ways that time can be conceived of in relation to the present and a future that is not-yetexistent. The article takes as its starting point ethnographic fieldwork in the $21^{\text {st }}$ century at a private, Catholic university in the U.S. and, in particular, men in an allmale residence hall. In focusing on this hall, it means to locate and localize the thinking in the context of the $21^{\text {st }}$ century as well as within the U.S., including neoliberalism as a social and economic method of relating.

Through the exploration of these men's envisioning of themselves as their future selves and the way they re-view the self that is now, this article makes a claim that they are - through both their actions, ways of relating, and the societal positioning - multiply liminal. Further, it will explore the way that through this temporal representation they are endowing themselves as permanently liminal both currently and in the future. The article situates these men amidst the university as an institution, as well as seeking to elucidate the importance of this temporal creation as a building of forms of transition and frontier.
\end{abstract}

Keywords: masculinity, higher education, time, liminality, residence hall, nostalgia 


\section{Introduction}

Memory is not an instrument for surveying the past but its theater. It is the medium of past experiences... (Benjamin 2006, xii).

There is a quote by Milan Kundera that says, "The struggle of man against power is the struggle of memory against forgetting" (Kundera 1996: 4). In context, Kundera was focusing primarily on the struggle against power. For the purposes of this article, it is important to think more heavily about the second element: memory and forgetting. Particularly the ways in which memories are created in such a way as to forego forgetting, or to work around the forgetting that will eventually happen by way of a temporal transition forward to the future from which to have a memory back against. This process is, in some ways, the opposite of Proust's In Search of Lost Time (2003) where the narrator/author looks back to come forward to the present. The object/action investigated here is not the searching for lost time, but the creation of time not yet had or lost.

This article takes as its starting ground ethnographic fieldwork undertaken at a private, Catholic university in the Midwest of the United States - called the University of St Jerome (USJ) - in an all-male residence hall. In locating the article in this way, it also means to set up not merely a global context, but a historical one the $21^{\text {st }}$ century United States - and a temporal one, as all of the men in the residence hall were first-year university students or in other words, 'freshmen'. While this article relies on ethnographic fieldwork, it is far more theoretically based rather than told through vignettes or fieldnotes. In my fieldwork I undertook numerous interviews and spent an entire year building up relations with these men. It is this that the following article speaks to and builds on.

Through this article I aim to begin exploring the connections between these men's experiences of university, time, and the way that liminality (beginning from: Turner 1967; 1969) plays a role in situating and creating these experiences. One might start with a brief but current definition of the term: "Liminality therefore suggests an impossibility of location within existing classifications and categorizations" (Haywood \& Mac an Ghaill 2013: 129). In particular, I aim to explore the way that the idea of permanent liminality - seen in part in Michael Kimmel's (2008) Guyland (though he does not narrate it this way) - is played out in these men's homosocial relations through the treatment of time as a frontier, and their experiences on campus and in the hall as a transition phase which one is liable to get stuck in. To do this I will first situate the university and set up some of the experiences of students. I will then analyze them and bring these experiences into relation with concepts of time, nostalgia, and permanent liminality. Unlike many early anthropological studies of time and people's understandings of time - which concretized entire cultures based on specific idioms, linguistic devices, or otherwise (Munn 1992) - this piece situates itself in both a specific context and suggests not that this 
is the way time is perceived in this context, but asks what this specific perception might suggest about these men, their place in society, their age, gender, race, class, and desires.

\section{The Men of Regan Hall}

Nestled amidst a bustling mid-sized Midwestern city, the University of St. Jerome (USJ) is a medium-sized university that boasts a wide range of majors, both graduate and undergraduate. While Catholic, $25 \%$ of its population self-identifies as nonCatholic, and its Catholic identity is something that many choose not to have as part of their collegial experiences. ${ }^{1}$ Like many US universities, USJ has a strong residential program, with a large number of residence halls scattered throughout the campus - there is also a two-year on-campus requirement for most students. ${ }^{2}$ Set just off the main part of campus sits Regan Hall, a 300-person all-male residence hall for first-year men. Regan is seen as the black sheep of the residence halls - due in large part to its status as the all-male residence, and to its position at the far end of the campus. Almost none of the men choose to live in Regan, but are instead assigned it, out of lack of space in other residence halls. This status as undesirables (as individuals) and unwanted (the building) put the community and the men in a position already in the midst of social conflict with other halls, and Regan men frequently express that they feel they are treated poorly due to where they live.

As all first year students, they are roughly 18 years old, and this comprises, for most, their first time living outside of the familial home. While many of them are from the surrounding area, they come from most states and internationally. Regan is set up in 'traditional' residential fashion, with students sharing a room with one other student and common area bathrooms on each floor. This type of housing much like all-male (or all-female) halls - is being phased out of most universities as they move to provide greater and greater amenities and choices to students. The building also has a series of common areas, notably the basement, called the 'Man Cave', which has couches, TVs, ping-pong, pool, and is a frequent spot for any number of activities within the building.

Like the university itself, most of the men in Regan are white and come from generally middle-class backgrounds, although with changes in universities in the U.S. in the past ten to twenty years, the class backgrounds of university students is also beginning to change (Stuber 2011), a fact the university has sought to capitalize on, to reach as wide a population as possible (Blacker 2013). The adaptation of educational systems has been well documented by Bowles and Gintis (1976), who, while not focusing on the university alone, demonstrate the ways that education is incorporating greater and greater degrees of individuals and doing so in such a fashion as to bring the system itself into the market. These changes though are still exceptionally gendered, classed and raced, and predicated upon a specific vision of 
university life that campuses are creating, seen in Armstrong and Hamilton's Paying for the Party, which documents the ways that universities are setting up pathways through college, many of which are built on parties, and specifically fraternities and sororities (2013).

Showcasing a distinctly different image of college life than Armstrong and Hamilton, Rebekah Nathan's My Freshman Year suggests a view of time that is tied, rather than to parties, to academics. "Clearly, the key to success was the careful management and control of our time (a.k.a. life)" (Nathan 2005: 111). ${ }^{3}$ Further, she says that "any kind of spontaneity threatened to thwart the best-laid plans" (Ibid. 112). These two images - along with Michael Moffatt's Coming of Age in New Jersey - are the three book-length ethnographies of residence halls, and in that way set up a backdrop upon which this fieldwork and theorizing finds itself.

\section{Students' Time: Fast \& Slow}

Having given some context and background of these men, I will move on to discussing the ways that they specifically situate themselves within a temporal and liminal frame through which they cast their lives, and which puts their experiences of life in and under university within a specific framework that might be called a nostalgia for the present. The act of 'speaking of time' is similar to Kunzel's description of men in prison:

\footnotetext{
In prison... 'time accumulates new dimensions.'... [It] distort[ed] conventional understandings of time as orderly, linear, and rationally clocked... Time, to prisoners, was something to be 'done'; prison time could be 'hard' or 'easy.' For some, incarceration took place in a strange and disorienting time out of time; for others; it suspended time altogether. (Kunzel 2008, 1)
}

While these men did not speak of easy or hard time, the ways that they expressed their experiences of time are shaped by a similar "time out of time". Almost all of the men that I spoke with talked about their experiences at college in two seemingly contradictory fashions, and which I asked them about as the topic came up.

For these men, their social relations with the other men in the building took primacy over most of their other relations, creating a form of kinship that worked outside of the heteronormative ordering and that was simultaneously not the same as fraternity brotherhoods. They spoke about their friends from Regan in ways that would indicate not only a deep connection but also a depth far deeper than what might have been imagined from the fact that they had known each other for less than nine months (by the end of the year).

Their relationships are imbricated with a necessitated time commitment. Interviewing many of the men, I asked them how much time they spent with their friends. While their answers varied, for many of them it was well over 40 hours a week, with a few guys ${ }^{4}$ responding that they spent up to 80 hours a week socializing with their friends. This level of intensity gave rise to, and was part of, the way their 
lives were temporally constructed. When they would leave for a long weekend going home for Thanksgiving or Easter - they would come back full of stories and longing to reconnect and catch up with their friends. It was like they had been away from each other for a period of years, when in fact it had only been three days. Asking them about their friends, they said that it felt like they had known them forever, and - in no uncertain terms - seemed to indicate that their friends were constitutive of their lives in a massive fashion.

Simultaneously, when I asked them how it felt to be almost finishing their first year of university and how the year had gone by, almost every one of them said the exact same words: "It went by like a flash". They felt that the year had flown by, leaving them breathless as the speeding rocket of a year neared its close in May.

Taken together, we can begin to see the first temporal quakes. They feel like they have known their friends forever, but the year has flown by. Put another way, one might suggest that in their friendships, time has moved slowly (giving the time together cavernous meaning), while the year has moved quickly (flying by). In the one period of time, time itself has moved in a polyrhythmic fashion. In doing this, they open up a way of viewing time as flexible. Not only is time both fast and slow, but it is also empty and overflowing.

Michel de Certeau talks about this phenomenon in relation to strategies and tactics:

\footnotetext{
Tactics are procedures that gain validity in relation to the pertinence they lend to time - to the circumstances which the precise instant of an intervention transforms into a favorable situation, to the rapidity of the movements that change the organization of a space, to the relations among successive moments in an action, to the possible intersections of durations and heterogeneous rhythms, etc (de Certeau 1988, 38).
}

He continues, saying "strategies pin their hopes on the resistance that the establishment of a place offers to the erosion of time; tactics on a clever utilization of time, of the opportunities it presents and also of the play that it introduces into the foundations of power" (de Certeau 1988: 38-39). Institutions or power-positions enact strategies; whereas tactics belong "to the other" (Ibid. xix). The heterogeneous rhythms of tactics play on the opportunities that they can, and in so doing thrust a spatial and temporal split into institutional and normative ways of seeing and doing time. These tactics are put to use by the men who I studied with as ways of altering and impacting their relationship not just to themselves (or their self), but to the broader situational constitution of power and institution that they find themselves encountering in their daily lives. Here one might list, and I will come back to this later, such things as: the university, their parents, the market, and societal treatment of adolescents.

The bending and playing with of time, for these students, is thus a challenge in some ways to specific norms and normatives. This usage and enactment of time runs counter to ideas of chrononormativity, which suggests that time be organized to maximize productivity (Freeman 2010). This form of schedule and life dictated 
around productivity is dramatically tied to capitalistic regimes of order, as well as to gendered visions of production and reproduction. This term seemed very apt for what I am investigating, and the way that these men determine their time based on productivity, and then, through processes external to the larger construction of time, seek to move outside the bounds of productivity.

\section{Students' Time: ...And Forward and Backwards}

That time is both experienced as fast and slow simultaneously is not so unusual; what is more important is the way that - having established a specific relation to temporal fluidity - they establish and narrate a nostalgia for the present that is neither in the here and now, nor in the future. Before theoretically discussing it, let me first establish more exactly the process by which they enact this nostalgia of a chronographic charting of time.

While hanging out with one group of guys, smoking on the front steps of Regan, they began talking about the future, in a sense. They were not talking about the future in the way that they were planning to do something in the future ("when I get older I will..."), but they were talking about it and thinking about the here and now. They talked about themselves as married 40-somethings (most likely with imaginary children), getting together and hanging out with their (male) friends. These friends are the friends that they are currently surrounded by on the steps - distinctly, and they are the only friends in the frame of vision. They sit around - again, presumably on a nice backyard deck or patio, surrounded by a big, green yard - drinking beers together, reminiscing about the 'good-old days'. The 'good-old days' though are, in fact, the very days that we are in at the moment, smoking a cigarette on the front steps of Regan. They are reminiscing about this exact moment. These guys - neither necessarily 'boys' nor 'men' - are searching out a 'good-old days' not only of their own imagining, but of that of their father's world (and therefore of a past that is just past). This vision they've created is an image out of Norman Rockwell, with dialogue written by Dali. They are transitioning their own selves, but are also - as with most generations - transitioning expectations from what their parents have given them to what they are able to now know.

In an instant they have gone forward twenty to thirty years - not passing through those years but merely jumping them as Evil Knievel jumped the Grand Canyon and then, from this future, looked backwards that exact same number of years (almost to the day). The jumping makes tenses difficult to differentiate or maintain, in this way I would suggest that the position in the future of looking backwards might be called the creation of future past presents. 


\section{Students' Time: Nostalgia for the Present}

It is important to distinguish this move from a simple idea of nostalgia. One might suggest, taking the clichéd phrase "the grass is greener", that nostalgia is the thought that, either forward or backwards, the grass was greener then. Whether the 'grass was greener back then' or 'the green will be greener soon', in either case, one might suggest that nostalgia is this rosiness tinting Ezra's glasses.

What is to be made though of things which might not fit into this idea? Frederic Jameson presents us with an interesting example. Taking his cue from a Phillip K. Dick novel set in a 1950s US that is not quite 1950s US, he discusses the way that "a formerly futurological science fiction (such as so-called cyberpunk today) turns into mere 'realism' and an outright representation of the present" (Jameson 1991, 286). Not only does science fiction - so often thought of as the unmitigated and unfurnished future - become reality in the sense that it is present (for those readers reading it in the 1950s), but, further, "the possibility Dick offered us - an experience of our present as past and as history - is slowly excluded" (Ibid.). While Jameson is talking about the broader conditions of time, memory, and possibility, he also lights up a way of seeing the ability for the overlapping of times, and the way that nostalgia - once enacted as forward looking - can be brought into the service of the present as well. Through the representation of the present (1950s), Dick is able to conjure up possibility as a temporal element, bringing potentiality into the chronocontext, while simultaneously making the presented future unreal.

These men, rather than merely looking forward or backwards to see the grass being greener on that side of the past/future, are in fact looking forward to look back and in doing so are seeking to see the present as better than it 'is' or than we are currently experiencing it. This process, which I will lightheartedly call dystalgia, is a process through the renegotiation of the now as better than it might be conceived, and, in so doing, adding weight to the importance of these events, actions, and the time itself. As a humorous aside, George Carlin once remarked that it seemed impossible to be nostalgic for something that had just happened an hour prior. "Can anyone explain to me the need for one-hour photo finishing? You just saw the fuckin' thing!" (Seeing his exasperated face dramatically adds to the impact of the response!) Yet, it seems, as we have been discussing, that one is able to be, while not necessarily nostalgic, hold affection and distilled impact for things that have just happened, those happening currently, as well as those which have not happened yet.

\section{Déjà vu, Memory of the Present, and Creation of Future Past Presents}

In so many ways, these men are not merely creating new forms of time but are in fact reacting and interacting with mnemonic devices and memory conceptually. "Rather than limit itself to preserving traces of times past, memory also applies 
itself to actuality, to the evanescent 'now"' (Virno 2015: 7). This 'now', is not simply here and now as itself, 'now', but is simultaneously experienced as both now and 'now' in the future looking backwards. "The instantaneous present takes the form of memory, and is re-evoked even as it is taking place. But what can 'remembering the present' mean, except having the irresistible sensation of having already experienced it previously?" (Ibid., 7). It is crucial to dive, briefly, into Paulo Virno's ideas, recently published, on the ways that déjà vu intersects with memory of the present, and from here, move forward to continue discussing the creation of future past presents.

"It is impossible to change something that has taken on the appearances of memory... they [individuals] become spectators of their own actions, almost as if these were part of an already known and unalterable script" (Virno 2015: 8). For Virno, those who create a memory in the present do so in a form of cynicism, and as a way of reducing themselves to spectators. Yet this is not so; not only so at least. One is able to create out of the present now a future that is alterable; the necessity that the future - which the now created in memory - elaborates, does not necessitate stagnancy. Through a reading of Bergson, who says that "there would be no memory at all, if it were not, first of all, memory of the present," he suggests that the reason the memory of the present in déjà vu is different is that rather than simply allowing perception to take that which it needs for "impending tasks", it instead prefaces perception with a remembrance of what is happening "while it is happening" (Ibid, 12).

He continues, elaborating on the idea that the distinction between perception and memory (again, taking from Bergson) is that perception "fixes the present as real, complete, resolved" while memory is "the modality of the possible" (Virno 2015, 14); the overlapping construction of a futurist-y memory of the present thus entangles both the real and complete (perception) with the realm of the possible (memory). "The synchronic operation of the two different modalities could provoke a hypnotic effect, dilating and congealing the immediate hic et nunc [here and now]" (Ibid. 15). In combining memory and perception one is able to be lulled into the concretized iteration of the present. Continuing, he says that "the possible is the hic et nunc made into an object of memory, placed under the sign 'back then', reevoked in the very moment in which it is lived" (Ibid. 17). This possibility (in memory) is evocative of both the present it is lived in, as well as the remembrance of the present lived in, and the future-future looking back at the past-present as was potentially lived as.

This back and forth, this reversion and movement, are of crucial importance for this discussion, as well as the point from which we take leave from Virno, away from déjà vu and towards a conception of the creation of future past presents. Virno is aiming at reflecting on the ways that the 'end of history' is conceptualized, and the elusiveness of a form of the memory of the present within this concept, and that undermines the project of the end of history. Here, rather, we are seeking to explore 
and extricate more a narrative, methodological idea of the memory of the present dis-related from broader historical ripples. To do this, we must go further into our understanding of time, and understandings of time rather than merely memory. In this, it means this article is distinct from studies of memory (such as: Ricoeur 1990, 2004; Wood 1991). Virno allows us to conceptualize and see the ways that these men, in their specific ways, are creating ideas about time in ways that are linked to broader conceptions of History (with a capital ' $\mathrm{H}$ ') and to a world system (in this case US neoliberalism) while simultaneously working through, around, and with norms and normatives about lives, life, and understandings of self.

Augustine, in his Confessions, says that there are three times: "a time present of things past; a time present of things present; and a time present of things future..." (Augustine, quoted in Virno 2015: 22). Continuing, he says, "The time present of things past is memory; the time present of things present is direct experience; the time present of things future is expectation" (Ibid. 22). One must then ask, where do these men's constitutions of a combined future that is simultaneously also past and present fit in this categorization?

\section{Aiming at Permanent Liminality}

It is, I would suggest, both exceptionally easy and impossible to answer that question. The easy answer is - as the set up for this article should suggest - liminality: they are betwixt and between. The difficulty though is that this liminality is not merely an ambiguity of condition, but something much more elusive and at the same time temporally ambiguous than what one might traditionally think of as liminal. Let us take as our starting place Victor Turner's statement on it:

The attributes of liminality or liminal personae ('threshold people') are necessarily ambiguous, since this condition and these persons elude or slip through the networks of classifications that normally locate states and positions in cultural space. Liminal entities are neither here nor there; they are betwixt and between the positions assigned and arrayed by law, custom, conventions. (Turner 1969: 95)

These young men sit within a variety of liminal positions (the multiplicity of their liminality is discussed below), but what is important here is the way that their liminal status is not merely based on temporal movements, but is also itself a temporal status implicated not temporarily - not as an adjustment to the tempo - but far closer to permanent, and as a leitmotif throughout the possible nows, futures, and future pasts. In this section and the following, I aim to further explicate that these men's future past present is not merely liminal singularly or temporarily, but is multiply and permanently liminal; in particular, utilizing Michel de Certeau's conceptions to theorize these processes and states further.

For de Certeau, rather than the concept/word liminality, he uses the idea of the bridge and frontier - an apt metaphor for US masculinity and men, whose identities are exhumed from a history of 'meritocracy', 'manifest destiny', and the 'wild wild 
west'. "The river, wall or tree makes a frontier. It does not have the character of a nowhere that cartographical representation ultimately presupposes. It has a mediating role" (de Certeau 1988: 127). In this sense, the frontier is itself not a non-entity, but a space unto itself - even if a space outside of common space. While the frontier is a mediating force, "The bridge is ambiguous everywhere: it alternately welds together and opposes insularities. It distinguishes them and threatens them. It liberates from enclosure and destroys autonomy" (Ibid. 128). The frontier and the bridge act as spaces of connection, points of touching. He says,

Thus, in the obscurity of their unlimitedness, bodies can be distinguished only where the 'contacts' ('touches') of amorous or hostile struggles are inscribed on them. This is a paradox of the frontier: created by contacts, the points of differentiation between two bodies are also their common points. (de Certeau 1988: 127)

These 'contacts' are the points of liminality, the spaces of in-between. They are, to put it metaphorically using de Certeau's verbiage, the bridge itself. Only the contact points hold them in place - no matter how liminal one is, they are still in contact with that which it is they are not. The liminal space of the bridge is one which is both always connected and yet always outside of; and, like all bridges, is also filled with forms of danger, failure, and risk of falling. These men, as they seek to put themselves in the future that is not, are actuating a frontier that is not creatable except as a form of fiction, which is distinct from untrue.

The amorous struggle is not, in this case, against another or Other, but against the Other that is their self not actualized yet. From a vantage point - that is itself between positions (the college student, who is conceived of as between adult/child) - they are remaking their future self as similarly between social locations. The stories that they are telling - the time(s) they are creating - are not merely impacting on the vision of the future enshrining of a liminal position but further elucidating a position in the here and now which is itself liminal. Further, these "stories are actuated by a contradiction that is represented in them by the relationship between the frontier and the bridge, that is, between a (legitimate) space and its (alien) exteriority" (de Certeau 1988, 126). The exteriority here becomes, in a sense, the position of a non-liminal position. In inverting the non-liminal position into the liminal position - through distalgia - they reposition themselves as cyclically exterior. In cre-ating their future selves as liminal, they position themselves continuously outside of structured and fixed positions, imposed by society, jobs, relationships, etc. In creating this possessed and possible future, these men are aiming towards both the unresolvable and the desired, which is simultaneously impossible.

If one were to collate this into a single sentence, it might look like this:

Come to college, collect friends, narrate distalgia into the future (i.e. longing for what they have, but in the future), and put yourself permanently in-between.

This permitting of a permeating in-between status is bound into the positions they occupy currently, and is furthered through a methodological enactment of distalgia 
that projects a nostalgia from their future selves backwards onto the self that is current, which is voiced by the self that is current, yet not the self the future nostalgia seeks to create.

\section{Liminality, Rupture, and Frontiers}

The frontier that these men create and cross creates instantiations of rupture, of spillage, of breakage. This is seen not only in the way they discuss the future, but the impacts that this has on the present. "As a transgression of the limit, a disobedience of the law of the place, it [the bridge] represents a departure, an attack on a state, the ambition of a conquering power, or the flight of an exile; in any case, the 'betrayal' of an order' (de Certeau 1988: 128). Through the ordering of themselves in the present as working towards a future where the present is different than its current-as-is state, they transgress not simply temporal bounds, but rupture sense and affects of social connectivity. It both springs bonds into the future - making friendships seem to blossom eternal - as well as pressurizes these relations in the now in such a fashion that it rips the relationship out of the simple present and puts it in a position outside of merely the interaction taking place. To come back to de Certeau, one final time, he reminds us that:

\footnotetext{
$\ldots$ at the same time as it offers the possibility of a bewildering exteriority, it allows or causes it the re-emergence beyond the frontiers of the alien element that was controlled in the interior, and gives ob-jectivity [sic] (that is, expressions and re-presentations) to the alterity which was hidden inside the limits, so that in recrossing the bridge and coming back within the enclosure the traveler henceforth finds there the exteriority that he had first sought by going outside and then fled by returning (de Certeau 1988: 128-129).
}

The bridge here continues to act as the liminal space, which simultaneously always connects itself at both ends, leaving that contact (touching) as the fluid travel between the present, the future, and the future past present.

These forms of rupture are contextual in both the sense that they have a context (place) as well as that they are driven by surrounding contexts. Ivor Southwood, reflecting on Marc Augé's 'non-places', suggests that in the 21st century more and more spaces have become outside of place - and are, therefore, out of place. He says that these non-places - such as retail parks, virtualized call centers, transitional spaces of communication - are themselves not just "placeless" but "amnesic" and act as "liminal zones" (Southwood 2011: 31). These non-places create neither "singular identity nor relations; only solitude and similitude" (Augé 1995: 103). One might similarly look to the ways that schools and the market are pushing men towards educational margins, particularly related to sexuality (Mac an Ghaill 1994). These non-places though, at the same time, open up creative uses of space rather than simply negating possibility. These men's friendships, in their own way, are 
opening up such a space and utilizing ways of being permanently liminal that stretch the borders of temporal and intimate boundaries.

It is important to return to the university, as an institution and powerful actor, sliding through our view of these men's interactions and ideas of time. In this, it is crucial to understand the way that the university - both as philosophical idea(l) and pragmatically-situated organization - is always contextual, to both a historical moment and a geographic locale. Universities in the US, at this moment (as well as historically), are places of social division and collection. Simon Critchley, commenting on this, suggests "Universities are phallic knowledge machines designed to accumulate at all costs. Capital and the university collide in the model of the rich American private university where the value of the institution really lies in the size of its endowment" (Critchley 2014: 128). He, humorously, reminds us that "everyone wants to be well endowed" (Ibid.). Universities are oft divisive in creating and being premised on homosocial meritocratic ideas (Rotundo 1993), where social life does not necessarily link, but can frequently be used to divide. This division, though - particularly amongst men (who were also the only ones originally allowed or given the opportunity to attend university) - also provided the basis for connection and an ethos of challenge to adulthood, the world, and the market.

"American ${ }^{5}$ college life was originally a new adolescent culture entirely of the students' own creation, arguably the first of the modern age-graded youth cultures that were to proliferate down to pre-teens by the late twentieth century" (Moffatt 1989: 29). While these rebellions and youth cultures were always partial - for example the birth of the fraternity in the US which pushed for independence from the faculty while simultaneously excluding students on the basis of religion and skin color - they are still an integral part of how one must contextualize micro visions of change. Put another way, one might suggest that they are part of the "reorganizations of education" that Leo Bersani and Adam Phillips (2008: 125) call for in concluding what is needed to open up new forms of intimacy. This call for new forms of intimacy is answered, if tentatively, by the haunted temporal and liminal vision of these guys' friendships and relations that reorient understandings of desire for selves and forms of relationality that bear no necessary correlation to a specifically-located bound, while at the same time acting as canaries for ways that neoliberalism processes individuals and the ways that individuals, in their pervasive resilience, are able to contest these iterations with counter narratives.

\section{Conclusion}

One might like to, if only playfully, begin the end by stating that: "After all, barring some life-erasing catastrophe, there will always be a future in the future" (Ruti 2008 , 114). Ruti is tackling what she calls the anti-social thesis in queer theory, playing tongue-in-cheek with Lee Edelman's book No Future (2004). While Ruti is tackling the ways and forms of sociality that are proffered and disavowed by 
Edelman, the concept of no future is one that ties back to ideas of queer time and queer space, in particular to Jack Halberstam. Halberstam says that

\begin{abstract}
if we try to think about queerness as an outcome of strange temporalities, imaginative life schedules, and eccentric economic practices, we detach queerness from sexual identity and come closer to understanding Foucault's comment in 'Friendship as a Way of Life' that 'homosexuality threatens people as a "way of life" rather than as a way of having sex' (310)". (Halberstam 2005: 1)
\end{abstract}

Without appropriating the idea of queer temporality, it seems fair to suggest that the figures and usage of time that these men work with does not necessarily fit the conscripted pattern of life which they are meant to be fitting and fulfilling. Further, he also suggests that we "rethink the adult/youth binary" and that which "lie(s) outside of those paradigmatic markers of life experience - namely, birth, marriage, reproduction, and death" (Ibid. 2). Halberstam, in presenting an alternative to more straight-laced (and straight) critical geographers (Jameson, Soja, Harvey), brings the heteronormative ordering into temporal and spatial understandings in a way that compliments previous understandings while shedding light on the complicated fashion through which sexuality - not merely the 'who's' of the sex act, but the ordered ordering of relations - can be shown to have dominant roles in this.

The argument of this article has meant to lay out the ways these men at university in the US today, a decade and a half after the turn of the century, are challenging notions of time through the use of forms of liminality that are not simple or singular. The forward motion to come backwards of these men's stories is both a temporal journey as well as a search for greener grass in the current; in where they are now. By putting themselves forward in a now that is not in fact now's now, they are seeking both to make their now seem better than it might in fact be, as well as putting themselves in a liminal position that is doubly betwixt and between. Yet, it is - at least partially - a world of their own creation. Between in the sense of time - as in neither here (the present) nor there (the future) - and life position (they are neither children nor adults; neither in college nor out of it).

In various ways, throughout the piece, these men's actions have been presented as liminal, situating them outside the bounds of childhood/adulthood, boy/man, powerless/powerful, here/there, now/then, and present/future, as well as various other positions. It is crucial to recognize the reality though that these men are still, in so many ways, the soon-to-be-s and the inheritors. Lynne Huffer sets out that the duel burdens of ethics are "the acknowledgement of harms, and, second, the active elaboration of alternatives to those harms" (Huffer 2013: 31). This piece has elaborated on the alternative possibilities that these men are creating by positioning themselves liminally, and by creating the protracted potential of a permanent liminal status. That does not, though, mean that they at all points acknowledge the harms of the system or their continued role in it. As such, it is important to not project onto them a utopian queerness which they neither seek, nor would be able to fulfill. 
In tabulating time and tempo, robbing nostalgia from the future like a thief, we must think back to the future that is both past, present and now. We need to think about the sketches and words being drawn onto them - "them" being both the men themselves and the "them" of their futures to be, futures to be created. Rene Ricard once said, in relation to graffiti lines and signatures, "In these autographs is the inherent pathos of the archaeological site, the cry down the vast endless track of time that 'I am somebody,' on a wall in Pompeii, on a rock at Piraeus, in the subway graveyard at some future archaeological dig" (1981). We will ask: who is the radiant child $?^{6}$ The question is both a reference to the title of Ricard's piece and is also meant to return us to the site of the future adult looking back at themselves, and seeing in that the burgeoning childhood of the university and the ways that the university sets up the space to be continuous and, potentially, permanently liminal.

Frank G. Karioris is a Doctoral Candidate in Comparative Gender Studies with a Specialization in Sociology and Social Anthropology at Central European University - Budapest, Hungary. His doctoral research is on men's homosocial relations in an all-male university residence hall in the United States. He is the co-editor, with Nancy Lindisfarne and Andrea Cornwall, of the forthcoming book Masculinities Under Neoliberalism (Zed Books 2016).

\section{Notes}

${ }^{1}$ There have been, in recent years, large debates about the 'Catholic identity' of the university and what role this should play. Many alumni and donors feel the school should be more explicitly Catholic, while the university itself seems to be moving towards a more secular position.

${ }^{2}$ Exceptions are primarily for non-traditional students and commuters.

${ }^{3}$ It should be noted that Nathan, a faculty member, lived in a primarily second-year dorm, and judging from her own admissions - did not gain access into the student's lives the way one might expect deep ethnographers might. This may, itself, be strongly linked to age and her position as (one might assume) clearly not a 'traditional' student, and who the students would feel distant from, as she was in at least her 40s when doing the fieldwork. Further, I would personally note that her method of covert ethnography (for which she also changed her authorial name - her real name is Cathy Small) is something that I do not support.

${ }^{4}$ Throughout this article, and my work more generally, I fluctuate between references to these individuals as "men" and "guys". This linguistic slippage is meant to highlight the fact that they are neither fully children nor fully adult - as is part of the larger argument of the piece. In using "guys" I seek to point to some of this ambiguity.

${ }^{5}$ In both this quote and Critchley's above, it is crucial to understand "American" as related specifically to the USA, rather than the broader Americas. This political distinction is important in recognizing the multiplicity of cultures within the Americas, and to dethrone the idea of the US as 'America' (in the singular).

${ }^{6}$ The reference - 'radiant child' - is also an homage to Jean-Michel Basquiat, who is one of the artists Ricard is discussing in his piece. 


\section{References}

Armstrong, Elizabeth A. and Hamilton, Laura T. (2013): Paying for the Party: How College Maintains Inequality, Cambridge, MA: Harvard University Press.

Augé, Marc (1995): Non-Places: Introduction to an Anthropology of Supermodernity, London: Verso.

Benjamin, Walter (2006): Berlin Childhood around 1900, London: Belknap Press of Harvard University Press.

Bersani, Leo and Phillips, Adam (2008): Intimacies, London: University of Chicago Press.

Blacker, David J (2013): The Falling Rate of Learning and the Neoliberal Endgame, Winchester, UK: Zero Books.

Bowles Samuel and Gintis, Herbert (1976): Schooling in Capitalist America, London: Routledge and Kegan Paul.

de Certeau, Michel(1988)The Practice of Everyday Life, London: University of California Pres.

Critchley, Simon (2014): 'What is the Institutional Form of Thinking?', The Undecidable Unconscious: A Journal of Deconstruction and Psychoanalysis, 1: 119-133.

Edelman, Lee (2004): No Future: Queer Theory and the Death Drive, London: Duke University Press.

Foucault, Michel (1996): 'Friendship as a Way of Life', Foucault Live: Collected Interviews, 1961 1984, edited by S. Lotringer, New York: Semiotext(e).

Freeman, Elizabeth (2010): Time Binds: Queer Temporalities, Queer Histories, London: Duke University Press.

Halberstam, Jack (2005): In a Queer Time and Place: Transgender Bodies, Subcultural Lives, London: New York University Press.

Haywood, Chris and Mac an Ghaill, Mairtin (2013):Education and Masculinities: Social, Cultural and Global Transformations, London: Routledge.

Huffer, Lynne (2013): Are the Lips a Grave? A Queer Feminist on the Ethics of Sex, New York: Columbia University Press.

Jameson, Frederic (1991): Postmodernism: Or, The Cultural Logic of Late Capitalism, London: Duke University Press.

Kimmel, Michael (2008): Guyland: The Perilous World Where Boys Become Men, New York: HarperCollins.

Kundera, Milan (1996): The Book of Laughter and Forgetting, London: Faber and Faber.

Kunzel, Regina (2008): Criminal Intimacy: Prison and the Uneven History of Modern American Sexuality, London: The University of Chicago Press.

Mac an Ghaill, Mairtin (1994): Making of Men: Masculinities, Sexualities \& Schooling, Buckingham: Open University Press.

Moffatt, Michael (1989): Coming of Age in New Jersey: College and American Culture, New Brunswick, NJ: Rutgers University Press.

Nathan, Rebekah (2006): My Freshman Year: What a Professor Learned by Becoming a Student, New York: Penguin Books.

Munn, Nancy (1992): 'The Cultural Anthropology of Time: A Critical Essay', Annual Review of Anthropology, 21: 93-123.

Proust, Marcel (2003): In Search of Lost Time: Swann's Way, Vol 1, New York: The Modern Library.

Ricard, Rene (1981): 'The Radiant Child', ARTFORUM Magazine Vol XX (4) (December): 35-43. Accessed online at http://izharpatkin.com/radiant_child/radiant_child.html.

Ricoeur, Paul (1990): Time and Narrative, Vol 1, London: The University of Chicago Press.

Ricoeur, Paul (2004): Memory, History, Forgetting, London: The University of Chicago Press.

Rotundo, Anthony (1993): American Manhood: Transformations in Masculinity from the Revolution to the Modern Era, New York: BasicBooks.

Ruti, Mari (2008) 'Why there is Always a Future in the Future', Angelaki: Journal of Theoretical Humanities, 13(1): 113-126.

Southwood, Ivor (2011): Non-Stop Inertia, Winchester, UK: Zero Books. 
Stuber, Jenny (2011): Inside the College Gates: How Class and Culture Matter in Higher Education, New York: Lexington Books.

Turner, Victor (1967): The Forest of Symbols: Aspects of Ndembu Ritual, London: Cornell University Press.

Turner, Victor (1969): The Ritual Process: Structure and Anti-Structure, London: Routledge and Kegan Paul.

Virno, Paulo (2015): Déjà Vu and the End of History, London: Verso.

Wood, David (Editor)(1991): On Paul Ricoeur: Narrative and Interpretation, London: Routledge. 